\title{
The Role of AdeABC, AdeFGH and AdelJK Efflux Pumps in Reduced Susceptibility to Tigecycline: Emergence of an Outbreak Associated With an International Clone Variant of Acinetobacter Baumannii Isolated From Burn Patients in Iran
}

\section{Research Article}

Keywords:

Posted Date: March 6th, 2023

DOI: https://doi.org/10.21203/rs.3.rs-1329296/v2

License: (c) (i) This work is licensed under a Creative Commons Attribution 4.0 International License. Read Full License 


\section{Abstract}

The full text of this preprint has been withdrawn by the authors while they make corrections to the work. Therefore, the authors do not wish this work to be cited as a reference. Questions should be directed to the corresponding author.

\section{Full Text}

The authors have withdrawn this preprint from Research Square. 